\title{
Research on the Path of Promoting the Development of Green finance in China Based on Internet Finance
}

\author{
Yanping Sun ${ }^{1, \mathrm{a}}$, Yongzhi Liu $^{2, \mathrm{~b}}$ \\ ${ }^{1}$ The Department of Economic and Managemen Harbin Huade University Harbin, China \\ ${ }^{2}$ The Department of Economic and Management Harbin Huade University Harbin,China
}

\begin{abstract}
As an important part of green finance, internet finance has certain advantages in promoting the development of green finance and is the main direction in promoting the development of green finance in China. The development of green finance can also create a better development environment for China's internet finance. The 14th Five-Year Plan is the development period of China's green finance, and "Internet + Green finance" will become a key breakthrough for China's financial industry reform and development. On the basis of a clear understanding of its own advantages in developing green finance, China's internet finance needs to understand the development requirements of green finance fully, strengthen its own strength, and explore the path of promoting the development of green finance actively from institutional cooperation, risk management, policy support, product innovation and other aspects.
\end{abstract}

\section{Introduction}

Green development is the common target of human development, and the development of "green finance" is one of the important measures to realize green development, also is an important part of the supply-side structural reform in our country. In the report at 19th CPC National Congress,President Xi Jinping stressed that China should strengthen the green finance, promote the construction of ecological civilization firmly, guide and encourage more social capital into the green industry through innovative financial system arrangement, restrain polluting investment effectively at the same time. As the representative of China's financial industry innovation and development, internet finance has gradually become a better carrier to promote the development of China's green finance. "Internet + Green Finance" has become a new highlight of the implementation of the "One Belt And One Road" initiative. The combination of "internet + " and green finance will help financial assets better serve the green reconstruction of the global value chain in the postindustrial economic era and provide a "Chinese model" for green innovation in global finance. How to make full use of its advantages to promote the development of China's green finance and then promote the development of China's green economy has become a topic worthy of further research. Taking internet finance promoting the development of green finance in China as the main research topic, this article defines the relationship between internet finance and green finance in detail, analyzes the current problems in promoting the development of green finance that internet finance faces in China, and then puts forward the path based on internet finance to practice and promote the development of green finance in China, so as to play a certain role in promoting the sustainable development of finance in China[1].

\section{Internet finance and green finance promoting each other}

\subsection{Internet finance}

Internet finance is a new financial business model that relies on means of big data, cloud computing and other modern scientific and technological information, and provide financial services. As an innovative pioneer in China's financial industry, compared with traditional finance, internet finance has incomparable advantages, such as less manpower investment, unlimited service, low operating cost, more personalized products, and high business processing efficiency, which are uniquely advantageous for the development of green finance.

\subsection{Green finance}

Taking environmental protection as a basic policy, green finance refers to finance that considers potential environmental impacts in investment and financing decisions, readjusts business philosophy, business process and business policies from the perspective of environmental protection. The main purpose of green finance is to support the growth of green economy and protect the ecological environment by integrating the potential risks, cost and benefits related to ecological and environmental protection into financial business processing fully. Green finance mainly guide capital flow 
into saving resources technology development and ecological environment protection industry, guide the enterprises pay attention to green production, using the financial business, to promote environmental protection and economy coordinated development, finally achieve the financial and economic healthy sustainable development[2].

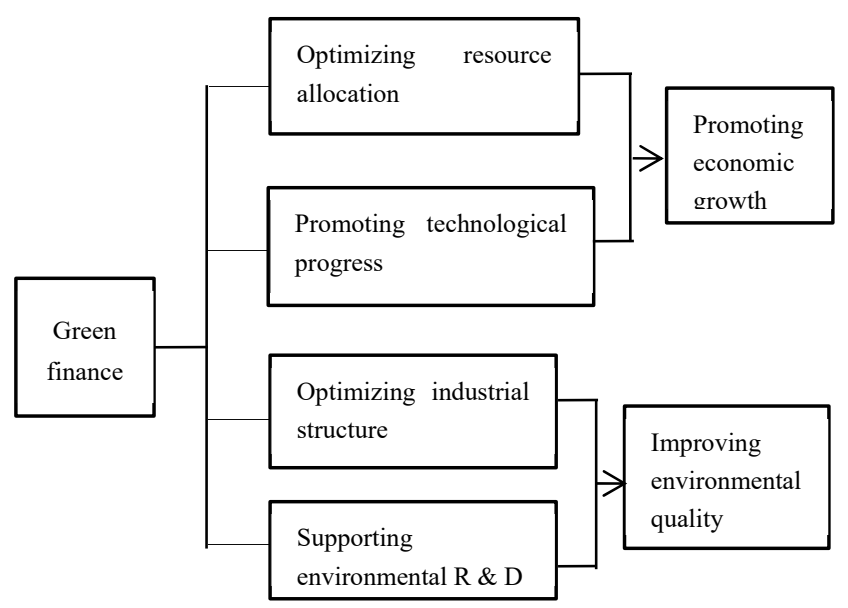

Figure 1. Green finance operation mechanism

\subsection{Internet finance and green finance complementing each other}

\subsubsection{Internet finance realizing the deep integration of green finance and green technology}

Internet finance is a green, friendly and innovative way of financial services. Digital technology makes it possible for the public to participate in financial services. Digital payment can reduce the use of cash, online banking services reduce the frequency of handling business at the bank counter, greatly improve the efficiency and scope of financial services, and reduce the original transaction cost and possible waste. Broadly speaking, industries related to internet finance, such as the sharing economy, are not only green, but also dark green. Take product crowdfunding as an example, that is, during the creative phase of a product, it tests possible market responses and consumer demands in the future to determine whether there is a market for the product, so there is no need to waste unnecessary production capacity construction and social resources for products without a market.

\subsubsection{Internet finance providing a new channel for financing the green industry}

Internet finance has given new vitality to the financing of green industry. The financing methods of "Internet + Financial Leasing" and "Internet + Crowdfunding" have reduced the financing cost of green enterprises in terms of capital and equipment. In addition, small and mediumsized enterprises accounted for more than $80 \%$ in the green industry supply chain. Therefore, the financing mode of "Internet + Supply Chain Finance" has effectively solved the financing difficulties of small and medium-sized enterprises and integrated the whole industrial chain. The strong data and model analysis ability of internet finance makes the operation of supply chain finance more efficient and improves the financing efficiency.

\subsubsection{Internet finance enriching the green financial system and promoting the development of green finance}

Internet finance has greatly enriched China's green financial product system, which mainly includes green credit and green bonds, making it more flexible in promoting the development of green finance. At the same time, the mobile and social characteristics of internet finance fit the consumption and investment habits of investors, so that green finance is recognized by more people, the group of green investment continues to expand, and the large increase of green funds will also help the development of China's green finance.

\subsubsection{Green finance providing a new direction for the development of internet finance and realizing the combination of industry and finance}

Supported by the national industrial economic policies, green finance, which has a huge market and financing demand, provides new materials for the development of internet finance. Financing methods such as green industry crowdfunding and financial leasing have a natural convergence point with internet finance platforms. Therefore, green finance is a new field in the development of internet finance. The application of internet finance in green finance, relying on large state-owned enterprises, private companies and other green internet financial platforms, combined with internet big data, serves the financing of the whole supply chain of green industry, and truly realizes the combination of industry and finance[3].

\section{The situation that internet finance promotes the development of green finance in China}

\subsection{China's internet finance and green finance have united to lead the world in green development}

China not only has the fastest growing and largest green financial market in the world, but also develops rapidly in the field of internet finance. Among the top 10 internet finance companies in the world, there are three Chinese companies, Ant Financial and JD Technology are the first and third respectively. In recent years, China's green finance has achieved rapid development, with the market size of green credit, green bond, green fund and other sectors ranking among the top in the world. By 2020, China's green loan balance has exceeded 11 trillion yuan, ranking first in the world, and the non-performing loan rate remained low. China's green bond issuance has also continued to grow sharply, and the cumulative issuance of green bond is about 1.2 trillion yuan, ranking second in the 
world. Since 2020, China's financial institutions have also actively applied internet finance to issue anti-epidemic green bond, which has played a positive role in promoting China's green recovery. The rapid development of green finance and internet finance has greatly promoted the development of China's ecological green industry and made China achieve remarkable achievements in the ecological field.China leads the world in the development of internet finance and green finance. If a strong integration, digital green finance anticipated [4].

Table1. Scale of China's green credit and green bond from 2016 to 2020

\begin{tabular}{|c|c|c|c|c|c|}
\hline & 2016 & 2017 & 2018 & 2019 & 2020 \\
\hline $\begin{array}{c}\text { Green } \\
\text { credit } \\
\text { balance }\end{array}$ & 75046 & 85000 & 96600 & 106800 & 115500 \\
\hline $\begin{array}{c}\text { Issuance } \\
\text { scale of } \\
\text { green bond }\end{array}$ & 2314 & 2483 & 2860 & 3656 & 2787 \\
\hline $\begin{array}{c}\text { Cumulative } \\
\text { issuance of } \\
\text { green bond }\end{array}$ & & 2314 & 4797 & 7658 & 11313 \\
\hline
\end{tabular}

Source: China's Green Finance Development Report (2016-2020)

\subsection{The financing scale of internet finance being large and risky}

The financing scale of internet finance in China is generally small, which cannot fully meet the capital needs of large-scale projects. Because of its short development time, the operation and development law of the financial industry is not clear, leading to poor professionalism. The combination of internet finance and green finance may have great financial risks. There are mainly two kinds of such financial risks: firstly, the risk management of internet finance itself is insufficient; secondly, the characteristics of relatively high volume and density of technologies in emerging industries mainly supported by green finance will also generate risks.

\subsection{Lack of professional competence in green finance and internet finance}

The effective application of internet finance in green finance requires users to have centralized and manageable big data application ability, perfect data governance mechanism and competent interdisciplinary talents in internet finance and environmental science. However, at present, China's financial institutions are generally short of green finance and internet finance professionals, professional tools for environmental risk management, and the support of environmental big data. The current means of identifying green finance projects or products is often provided by third-party professional environmental agencies. The personnel of third-party environmental institutions are generally not familiar with financial application scenarios, and the service mode is offline, with relatively high cost and poor timeliness.

\subsection{Lack of product and industrial agglomeration effect}

With the construction of China's green financial system, green fund, green insurance, green trust, green PPP, green lease and other regional new products, new services and new forms of business continue to emerge, and the application of green financial products, tools and business models supporting internet finance needs further research and improvement. However, due to different business scenarios and different product objects, most of which contain confidential business information, the application of new technologies is difficult to form economies of scale. In addition, due to the lack of clear regulatory standards and requirements, some financial enterprises are afraid of the uncertainty and risks brought by the use of the internet and dare not invest in research and development first. At the same time, because the technology and application of the internet to support the development of domestic green finance are in the initial stage, with few practical achievements, the industrial agglomeration effect brought by green technology industrial parks and other green technology industrial clusters has not yet been formed[5].

\section{The path of Promoting the development of Green finance in China under the Internet finance}

\subsection{Cooperating with traditional financial institutions actively}

Although internet finance has played a very important role in the development of green finance, there are still some problems that need to be paid attention to. For example, the current capital scale of internet finance has not reached a certain extent, and the rise time is relatively short, so the financial industry lacks certain professionalism. In the face of these problems, internet finance must actively cooperate with traditional financial institutions, make use of their professional technology and capital advantages, gradually expand the source of their customers, pay attention to risk management issues, and provide a strong reserve force for the development of green finance in the process of promoting the development of green finance. At the same time, we should make full use of our strong advantages in science and technology, communicate with traditional financial institutions in the cooperation process, and guide them to strengthen their support for energy conservation, environmental protection, ecological protection, clean energy investment and other science and technology industries, so as to further promote the rapid development of green finance.

\subsection{Encouraging internet financial enterprises to develop green financial ecology through policy promotion}

Although the country is advocating green finance at present, the development mechanism in this aspect is not perfect yet. As an effective means of green finance 
development, internet finance should actively promote policy support, establish relevant mechanisms to promote green finance development with the government jointly, strengthen government support, ensure the effective combination of internet finance and green industry, create a good policy environment for the development of internet finance, and ensure adequate resources for the development of green finance. At the same time, with the rapid development of internet finance in recent years, relevant institutions should participate in the formulation of regulatory policies in order to better improve the feasibility of relevant policies, and provide greater policy benefits for the development of green finance in the process of specific policy formulation, so as to lay a good foundation for the rapid development of green finance in China.

\subsection{Building a modern green financial information sharing platform}

Internet finance should actively serve local green financial reform, establish a docking platform between green finance (such as bank credit and equity investment) and green projects, focus on online matchmaking of green credit business, realize "one-stop" supply of green financing for enterprises, realize data integration, information sharing and real-time monitoring of green financing among different channels, improve the docking efficiency of green financing, realize rapid docking of preferential policies from the government and green projects, and simplify application and implementation. Internet finance can serve the green financial reform of local governments, integrate the information and data of multiple government departments, establish a green credit information system including ESG information of various enterprises, and establish a financial information statistics platform to help financial regulatory authorities improve regulatory efficiency. Through real-time collection, statistical analysis and management application of green finance business information,internet finance provides sufficient information and data basis for green finance supporting policies and derivative transactions[6].

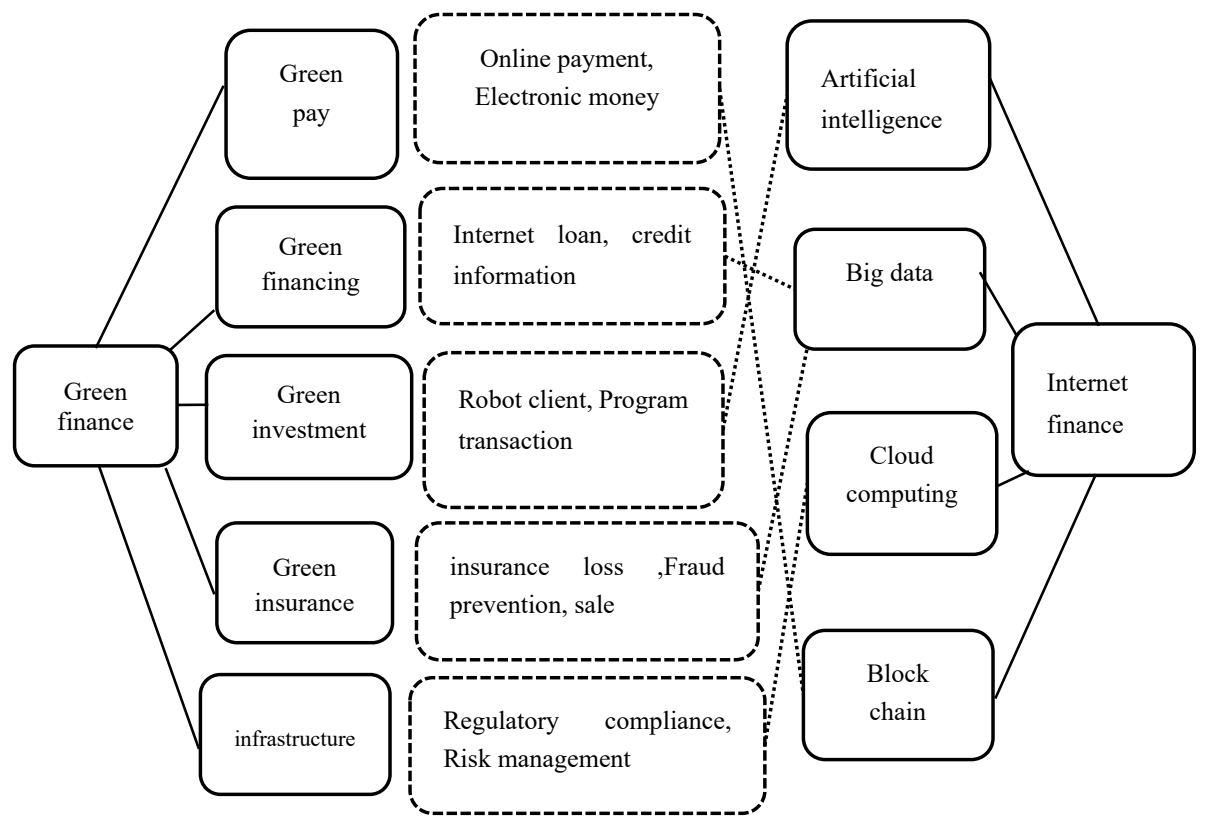

Figure 2. "Internet + Green finance" Deep Integration Model

\subsection{Improving the environmental risk identification capability of green financial institutions}

In the process of green financial development, internet financial enterprises should make full use of its advantages and internet information means such as use of big data, control the financial risk. By using the ability to monitor the environmental performance of enterprises integrated with internet finance and through big data technology to obtain the environmental performance information of target customers, internet financial enterprises can help green financial institutions find out whether customers have environmental risks as early as possible, realize real- time collection, statistical analysis and risk early warning, and develop corresponding strategies and schemes. By using technologies such as block chain, internet financial enterprises can solve the problem of funds through the management, help financial institutions to implement green credit, green bonds to trace, help reduce the risk of "green washing".

\section{Conclusion}

In general, in the process of promoting the development of green finance, internet finance should give full play to its own advantages, analyze the credit status of customers by means of big data and cloud computing, and make good use of professional technical methods to manage the risk 
of customers. At the same time, it is necessary to study the government's guiding policies deeply to ensure that its business conforms to the government's policies and effectively avoid some policy risks. In addition, it is necessary to cooperate with traditional financial institutions to help internet finance identify risks effectively with their professional capabilities, so as to improve its risk management level effectively and promote the rapid development of green financial industry ultimately.

\section{References}

1. Feipeng Lou., "The advantages and paths of internet finance promoting the development of green finance," The western financial, pp. 4-7, June 2018.

2. Jin Zhang, "Development path choice of internet finance in China from the perspective of inclusive finance," Financial Development Review, vol. 84, pp. 146-150, Jan 2018.

3. Minfeng Chen and Liang Yang, "An Analysis of the development status and growth prospects of green internet finance-Based on the re-examination of the connotation of green finance," Research on Rural Finance, pp. 37-42, July 2017.

4. Peixiong Yan, "Research on the idea and path of promoting the sustainable and healthy development of Green finance in China," Journal of Hubei University of Economics (Humanities and Social Sciences edition), vol. 13, pp. 58-59, Sept. 2016.

5. Ke Dong, "Internet finance facilitating the development of green finance," Modern marketing, pp. 42-43, Jan. 2019.

6. Fengrong Wang and Kangshi Wang, "The development mode and promotion path of green finance-Based on the green transformation perspective," The theory of journal, vol. 277, pp. 6168, Mar. 2019. 